Plant Tissue Cult. \& Biotech. 21(2): 161-168, 2011 (December)

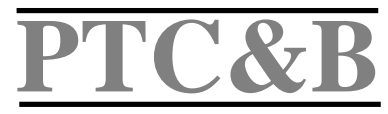

\title{
Investigation into Seasonal Effect and Browning Inhibitor on Callus Regeneration of Seedless Barberry (Berberis vulgaris var. asperma)
}

\section{Morteza Mohammadi*, Abdolreza Bagheri, Hasan Marashi, Nasrin Moshtaghi and Ahmad Balandari ${ }^{1}$}

College of Agriculture, Ferdowsi University of Mashhad. P.O. Box 91775-1163, Mashhad, Iran

Key words: Seasonal effect, Browning inhibitor, Berberis vulgaris

\begin{abstract}
Leaves, one year old stems and buds were used as explants. WPM, B5, MS, half and one-fourth strength MS with 2,4-D, NAA, IBA, IAA and picloram 2, 5 and 10 $\mathrm{mg} / \mathrm{l}$ were used for callus induction. Investigation into the seasonal effect on callus regeneration and explants browning was carried out in mid-April until September. Results showed that washing with sterile distilled water for one hour after surface sterilization was the best treatment for browning inhibition of explants than other treatments. Leaf explants have best callus formation. MS with $8 \mathrm{~g} / \mathrm{l}$ agar had strong effect on callus formation. Culture for callus formation in May and June found to be higher than other months. 2,4-D, NAA and $10 \mathrm{mg} / \mathrm{l}$ picloram significantly enhanced callus formation. Leaf and bud explants sampling in April to May did not show any endophyte contamination but leaf explants in June until September, specially the one year old stems, showed intensive contamination.
\end{abstract}

\section{Introduction}

Seedless barberry (Berberis vulgaris var. asperma) is one of the most important medicinal fruit plants of South Khorasan Province in Iran. This dicot perennial plant is cultivated for producing fruits. Barberry is consumed for cooking and producing jam in Southwest Asia specially in Iran and Europe (Moghaddam et al. 2007). The genus Berberis contains a complex of secondary metabolites such as berberin, berlambine, oxyberberine, oxycanthine, chlorumamine, anthocyanine, bervulcine, lambertine and magniflorine, which are frequently used in the pharmaceutical industry (Arayne et al. 2007).

${ }^{*}$ Author for correspondence. ${ }^{1}$ Khorasan Research Institute for Food Science and Technology, Mashhad, Iran. 
Cell suspension and hairy roots were cultured for producing secondary metabolites (Rao and Ravishankar 2002). Different stages of tissue culture make more complex by explant browning (Murkute and Mayakumari 2003). Browning is affected by some factors such as type and age of explants, genotype, season for preparing of explants, pre-treatments, method of sterilizing, media, PGRs, light, temperature and frequent subculture (Tian 2008). Browning also is caused by the presence of endophytes (Pirttila et al. 2008). Endophytes include microorganisms which are found within plant tissues without any symptoms that they might be bacteria or yeast. Study on Scots pine showed that endophyte can stimulate production of chitinase enzyme, which is the starting point for browning chain reaction (Pirttila et al. 2008). Some workers emphasized that endophytes have positive impact on callus organogenesis and embryogenesis (Holland and Polacco 1994). In genus Berberis there is no report about endophytes.

Tissue culture in seedless barberry has not yet been reported. However in some species of genus Berberis, micropropagation and secondary metabolite production have been reported. Breuling et al. (1985) produced berberine, palmatine, columbamine and jatrorrhizine in cell suspension of Berberis wiisonae. For micropropagation of Berberis trifoliata Moric, shoots $(1.5 \mathrm{~cm})$ were cultured in vitro for 30 months before rooting treatment. WPM medium plus MS vitamins and $0.8 \%$ phytagel supplemented by IBA and NAA were used for rooting. Results showed that NAA $(1 \mu \mathrm{M})$ was effective for rooting (100\%). Rooting (60 $80 \%)$ was observed in media with IBA $(4.9 \mu \mathrm{M})$, IBA $(12.3 \mu \mathrm{M})$ and NAA $(5.4$ $\mu \mathrm{M})$. But rooting did not form in media with IBA $(0.5 \mu \mathrm{M})$ and NAA $(26.8 \mu \mathrm{M})$ (Mackay et al. 1996). Arena et al. (2000) had success in micropropagation of $B$. buxifolia using stem explants on MS with IBA $(1.25 \mu \mathrm{M})$ and then subculturing in the medium without PGRs. Moreover, Arena et al. (2005) showed that polyamine compounds, (putrescine, spermidine and spermine) in MS with IBA $(1.25 \mu \mathrm{M})$ can increase the rooting percentage in micropropagation of B. buxifolia.

The only study on in vitro culture of seedless barberry was carried out by Aghabozorgi (2006). In that study, explant browning occurred in callus formation stage of leaf explants. But that study failed to prevent browning by using antioxidant, darkness treatment, subculture, culture in modified MS (halfand one fourth-strength of MS) and cold treatment (Aghabozorgi 2006).

In this study, factors such as the kind of medium, gelling agent, kind of PGRs and their concentration, season effect and browning inhibitors were investigated on callus induction and browning inhibition. 


\section{Materials and Methods}

Plant materials were provided from seedless barberry shrubs in greenhouse of Ferdowsi University of Mashhad, Iran. One year old stems, leaves and buds, were used as explant. Surface sterilization was done by $1 \%$ sodium hypochlorite with Tween 20 for $7 \mathrm{~min}$ and then washing three times with sterile distilled water for $5 \mathrm{~min}$.

Different media such as WPM, B5, half- and one fourth-strength MS with two gelling agents: $8 \mathrm{~g} / \mathrm{l}$ agar and $2 \mathrm{~g} / \mathrm{l}$ phytagel, each with 10 replications were used. For preparing half- and one fourth-strength of MS, only macro element salts decreased and other elements were the same as MS. Factorial experiment in completely randomized design was used for analysis.

For investigating the effect of 2,4-D, NAA, IAA, IBA and piclorum $(2,5$ and $10 \mathrm{mg} / \mathrm{l})$ and IBA + IAA combinations $(1+1,2.5+2.5$ and $5+5 \mathrm{mg} / \mathrm{l})$ and control, each with 10 replications in MS, $8 \mathrm{~g} / \mathrm{l}$ agar and leaf explants were applied in separate experiments.

Inhibitors (Table 1) were used to avoid browning in explant and callus formation. Data analysis was made using completely randomized design.

To evaluate the season effect, leaf sampling was made on mid-April until August.

Table 1. Browning inhibitors with their levels.

\begin{tabular}{ll}
\hline Treatment & Usage methods \\
\hline Control & ---- \\
P.V.P & 1 and $2 \mathrm{~g} / \mathrm{l}$ \\
Ascorbic acid & 150 and $300 \mathrm{mg} / \mathrm{l}$ \\
Etiolating & Two weeks and to end \\
Washing with SDW & 0.5 and 1 hour \\
Liquid culture & Liquid culture with paper bridge \\
Subculture & Every 3 days and weekly \\
Modified MS & Half- and one-fourth strength MS \\
Glutamic acid & 1 and 2 g/l instead of nitrate salts \\
\hline
\end{tabular}

Data containing dry weight and percentage of callus formation were recorded. Analysis of variance, mean comparisons (HSD test) and chart drawing were done by JMP4 and Excel 2007 software.

\section{Results and Discussion}

Highest $(70 \%)$ callus formation was obtained from leaf explants and bud explants had the minimum induction. Some bud explants produced similar structure such as barberry fruit after several months (Fig. 1B). Callus did not 
generate on one year old stems. Browning and endophyte contamination intensively occurred on them compared to other explants after three months. Leaf explants larger than $2 \mathrm{~cm}^{2}$ generated erratic callus. Leaf explants with 1.0 $1.5 \mathrm{~cm}^{2}$ surface generated lighter color and better structure callus than large leaves (Fig. 1A). Leaves smaller than $0.5 \mathrm{~cm}^{2}$ showed slowly and tiny callus induction.
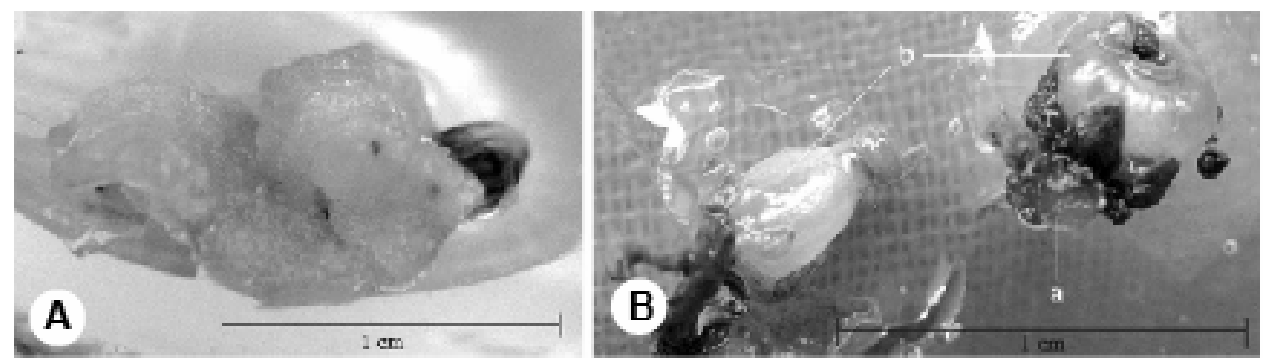

Fig. 1. Suitable callus generation in leaf explants (A). Dehiscence bud in medium containing $10 \mathrm{mg} / \mathrm{l}$ piclorum five months after culture (B).

Leaf explants in MS with $8 \mathrm{~g} / \mathrm{l}$ agar exhibit maximum callus regeneration. Callus was induced slowly on B5 medium which was more vitrificated than those on MS. Little difference was observed between WPM and B5 media. GAs and media had significant difference $(\mathrm{p} \leq 0.05)$. In all treatments, media with $8 \mathrm{~g} / \mathrm{l}$ agar were better than media with $2 \mathrm{~g} / \mathrm{l}$ phytagel (Fig. 2).

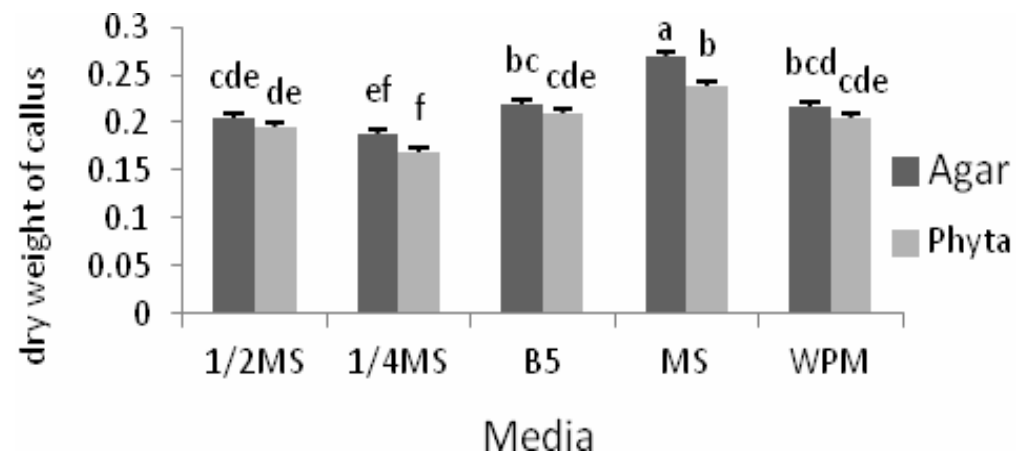

Fig. 2. Callus dry weight in different media (different letters show significant difference, $\mathrm{p} \leq 0.05$ ).

Explant washing with sterile distilled water was more effective than other treatments. Washing following by PVP and activated charcoal was better for inhibition of browning than control. Other treatments did not inhibit browning showing explants and media were completely brown after 10 - 20 days (Fig. 5). Activated charcoal absorbs plant growth regulators (PGRs), therefore low callus 
formation was observed in this treatment and the explants and callus were dried after some time.

2,4-D, NAA and piclorum $(10 \mathrm{mg} / \mathrm{l})$ showed the highest callus regeneration $(\geq 60 \%$ ). Callus on piclorum treatment at $10 \mathrm{mg} / \mathrm{l}$ was much more and had better structure than 2,4-D and NAA treatment at the same level. Callus induction percentage and the average of callus dry weight are shown in Table 2.

Table 2. Average callus dry weight and callus generation percentage in different PGRs with different concentrations (different letters show significant difference, $\mathrm{p} \leq$ 0.05).

\begin{tabular}{|c|c|c|c|c|c|c|c|c|c|}
\hline PGRs & \multicolumn{3}{|c|}{ IAA } & \multicolumn{3}{|c|}{ IBA } & \multicolumn{3}{|c|}{ IAA+IBA } \\
\hline Conce. (mg/l) & 2 & 5 & 10 & 2 & 5 & 10 & 2 & 5 & 10 \\
\hline Callus dry wt. (g) & $0.07 \mathrm{e}$ & $0.07 \mathrm{e}$ & $0.013 \mathrm{~cd}$ & $0.08 \mathrm{e}$ & $0.08 \mathrm{e}$ & $0.14 \mathrm{c}$ & 0.09 de & $0.12 \mathrm{~cd}$ & $0.15 c$ \\
\hline Callus formation (\%) & $10 \mathrm{~g}$ & $10 \mathrm{~g}$ & $30 \mathrm{e}$ & $10 \mathrm{~g}$ & $20 \mathrm{f}$ & $20 f$ & $10 \mathrm{~g}$ & $20 f$ & $40 d$ \\
\hline
\end{tabular}

(contd.)

\begin{tabular}{|c|c|c|c|c|c|c|c|c|c|}
\hline PGRs & \multicolumn{3}{|c|}{ NAA } & \multicolumn{3}{|c|}{$2,4-\mathrm{D}$} & \multicolumn{3}{|c|}{ Piclorum } \\
\hline Conce. (mg/l) & 2 & 5 & 10 & 2 & 5 & 10 & 2 & 5 & 10 \\
\hline Callus dry wt. (g) & $0.14 \mathrm{~cd}$ & $0.13 \mathrm{~cd}$ & $0.27 \mathrm{a}$ & $0.14 \mathrm{c}$ & $0.16 \mathrm{c}$ & $0.26 a$ & $0.21 b$ & $0.22 b$ & $0.30 \mathrm{a}$ \\
\hline Callus formation (\%) & $20 \mathrm{f}$ & $40 \mathrm{~d}$ & $60 b$ & $20 \mathrm{~F}$ & $50 c$ & $60 b$ & $30 \mathrm{e}$ & $50 c$ & $70 \mathrm{a}$ \\
\hline
\end{tabular}

Culture of Berberis tissue in May and June showed maximum callus regeneration. Little callus regeneration was observed in April but low browning was observed too. Tissue culture in August and September severely showed endophyte contamination and paleness after about 20 days. Dry weight of callus in the April until August is shown in Fig. 3.

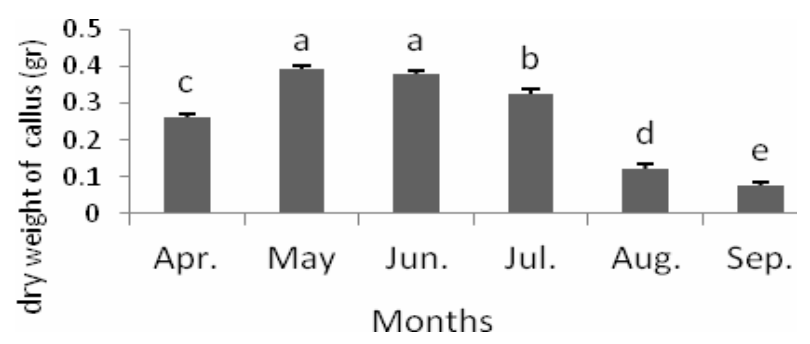

Fig. 3. Season effect on callus dry weight (different letters show significant difference, $\mathrm{p} \leq 0.05)$.

Leaf explants have superior callus induction due to minimum injury during preparation. Lee and Whitaker (1995) explained the explant browning due to oxidation of polyphenols and their leakage because of the confusion in the cell. 
Leaf explants were prepared from petiole with a small incision but one year old stem explants were supplied by one slice on either side of the explants that cause cellular injury and turmoil.
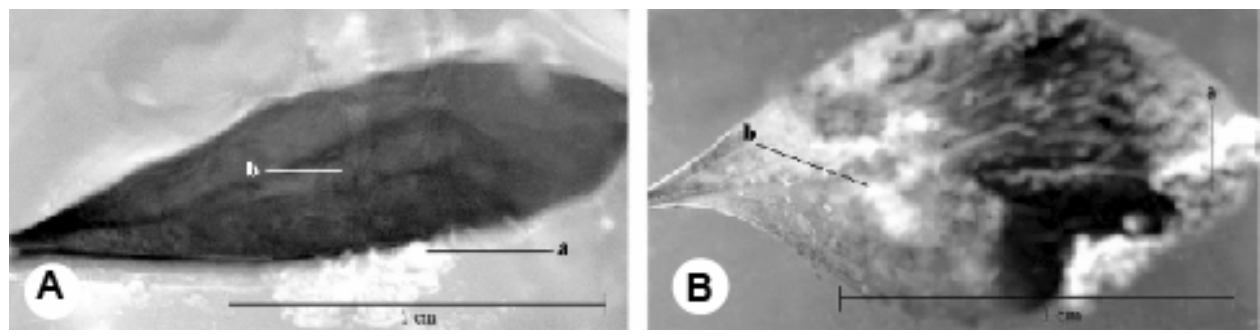

Fig. 4. A. (a) Endophyte colony entered the culture medium three months of culture in September, (b) explants were black. B. Typical irregular callus regeneration on leaf explants in September, (a) powdery and (b) jelly callus.

Only a few calli were regenerated in April, which was probably due to the low amount of food storage in the explants.

It seems that jelly and powdery calli shape in August and September and separation small lump callus of leaves with surface larger than $2 \mathrm{~cm}^{2}$ is due to much distinction of these explants (Fig. 4B). Mature leaves transformed to barb at the end of year (Kafi and Balandri 2004). In environmental stress such as drought, normal callus was not produced from explants in August and September.

Apparently, seedless barberry is sensitive to high humidity. Explants in liquid tissue culture with paper bridge started browning early. Incidence of such browning was also reported by other workers (Aghabozorgi 2006).

Browning can be classified in two categories: Enzymatic and non-enzymatic. In enzymatic process, series of enzymes such as polyphenoloxidase oxidized polyphenols in presence of light and oxygen and in non-enzymatic type, plant material was destroyed in the presence of polyphenolic compounds (Tian 2008).

Darkness treatment prevents the peroxidase activity (Chen et al. 2002) and antioxidants inhibit the activity of polyphenoloxidase enzyme by absorbing oxygen. Polyphenoloxidase activity caused browning and decaying of cells (Tang and Newton 2004). Comparison of the results of antioxidant, darkness and washing treatments show that browning in seedless barberry was due to high amount of polyphenolic substances in explants and as such washing the explants in sterile distilled water was the best approach. PVP and activated charcoal absorb polyphenolic substances as a result media are suitable for culturing explants barberry plant. 
Endophytes appear in seedless barberry after browning. When endophyte increased in plant, the tannin also increased and the explants became browning at the end (Pirttila et al. 2008). These microorganisms (Endophytes) display in plants through cell pathways; therefore, they have slow motion. As a result of rapid growth of bud explants and leaves in April, endophytes cannot reach this organ, therefore contamination was not observed in explants (Fig. 4A).

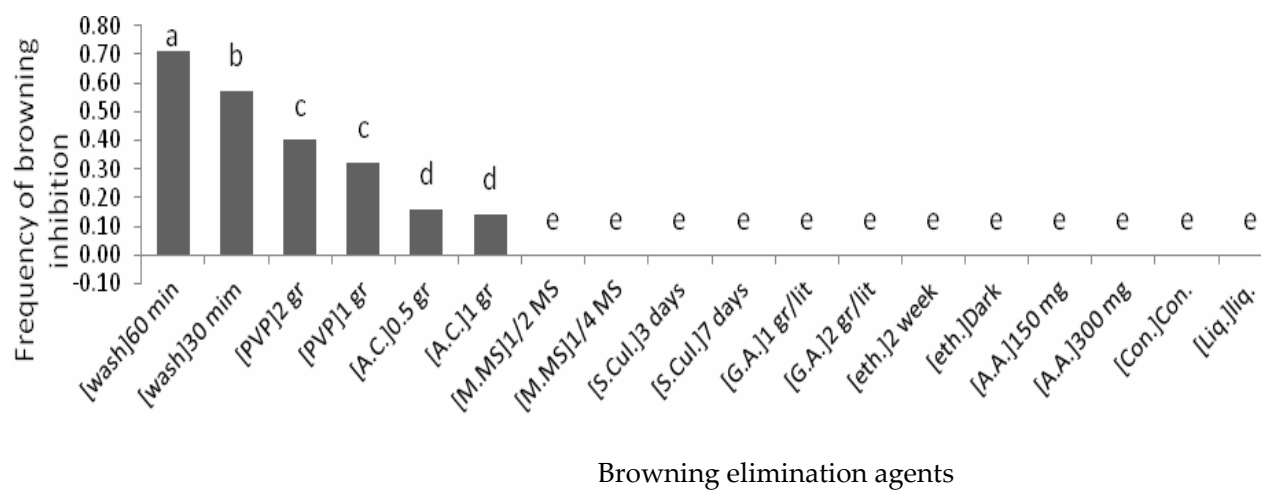

Fig. 5. Effect of different treatments to prevent browning by washing the explants with sterile distilled water after surface sterilizing, AC: Activated carbon, MMS: Modified MS, S. cul.: Subculture, GA: Glutamic acid instead of all nitrate salts, eth.: Dark treatment, AA: Ascorbic acid, Con: Control. Liq.: Liquid tissue culture, Different letters show significant difference, $\mathrm{p} \leq 0.05$.

Frequent subcultures have opposite effect on browning inhibition. In some species, namely B. trifoliata, subculture prevented explant browning (Mickey et al. 1996) but subculture in seedless barberry caused browning. Subculture for browning inhibition in peony (Paeonia suffruticosa Andr.) had negative effect (Lang and Lu 2007), however some reports emphasized on the positive effect of subculture in regeneration of this species (Tian 2008).

According to present research, callus regeneration in seedless barberry has been influenced by several factors. Controlling of all these factors together caused better callus induction with high regeneration which may provide a background for future studies.

\section{References}

Arayne SM, Sultan NS and Pharm PJ (2007) The Berberis story: Berberis vulgaris in therapeutics. Pak. J. Pharm. Sci. 20: 83-92.

Arena ME, Benavides MP and Curetto N (2005) Polyamines and inhibitors used in successive culture media for in vitro rooting in Berberis buxifolia. New Zealand J. Bot. 43: 373-380. 
Arena ME, Pastur GM and Vater G (2000) In vitro propagation of Berberis buxifolia Lam. Biocell 24: 73-80.

Aghabozorgi M (2006) The study of rooting response of some horticulture plants after inoculation with Agrobacterium rhizogenes. M. Sc Thesis. Ferdowsi University of Mashhad, Iran.

Breuling M, Alfermann AW and Reinhard E (1985) Cultivation of cell cultures of Berberis wiisonae in 20-1 airlift bioreactors. Plant Cell Reports 4: 220- 223.

Chen LM, Cheng JT, Chen EL, Yiu TJ and Liu ZH (2002) Naphthaleneacetic acid suppresses peroxidase activity during the induction of adventitious root in soybean hypocotyls. J. Plant Physiol. 159: 1349-1354.

Holland MA and Polacco JC (1994) PPFMs and other covert contamination: is there more to plant physiology than just plant? Annual Rev. Plant Mol. Biol. 45: 197-209.

Kafi M and Balandari A (2004) Barberry (Berberis vulgaris): Production and Processing, Ferdowsi University Press. p. 20.

Lang YT and Luo XF (2007) The research on callus induction and browning prevention of peony. J. Henan. For. Sci. Technol. 27: 4-6.

Lee CY and Whitaker RJ (1995) Enzymatic browning and its prevention. American Chemical Society, Washington. pp. 337-338.

Mackey WA, Molinar FJR, Wall MM and Cardenas M (1996) Micropropagation of Agarita, Berberis trifoliata Moric. Hort. Sci. 31: 1030-1039.

Moghaddam PR, Huda AKS, Parvez Q and Koocheki A (2007) Indigenous knowledge in agriculture with particular reference to medicinal crop production in Khorasan, Iran. World Association for Sustainable Development. pp. 105-115.

Murkute AA and Mayakumari SP (2003) Exudation and browning in tissue culture of pomegranate Agr. Sci. Digest. 23: 29-31.

Pirttila AM, Podolich O, Koskima ki JJ, Hohtola E and Hohtola A (2008) Role of origin and endophyte infection in browning of bud-derived tissue cultures of Scots pine (Pinus sylvestris L.). Plant Cell Tiss. Org. Cult. 95: 47-55.

Rao Ramachandra S and Ravishankar GA (2002) Plant cell cultures: Chemical factories of secondary metabolites. Biotech. Adv. 20: 101-153.

Tang W and Newton RJ (2004) Increase of polyphenol oxidase and decrease of polyamines correlate with tissue browning in Virginia pine (Pinus virginiana Mill.). Plant Sci. 167: 621-628.

Tian D (2008) Container production and post-harvest handling of Lotus (Nelubo) and micropropagation of herbaceous peony (Paeonia). Ph.D. Thesis Auburn University, USA. 